\title{
A 10-year analysis of the oral squamous cell carcinoma profile in patients from public health centers in Uruguay
}

\section{Maria Laura Cosetti OLIVEIRA(a) Vivian Petersen WAGNER(b) Manoel SANT'ANA FILHO(b) Vinicius Coelho CARRARD(b) Fernando Neves HUGO(c) Manoela Domingues MARTINS ${ }^{(b)}$}

(a) Univesidad de la República - UDELAR, School of Dentistry, Department of Oral Pathology, Montevideo, Uruguay.

(b) Universidade Federal do Rio Grande do Sul - UFRGS, School of Dentistry, Department of Oral Pathology, Porto Alegre, RS, Brazil.

(c) Universidade Federal do Rio Grande do Sul - UFRGS, School of Dentistry, Center of Community Dental Health Research, Porto Alegre, RS, Brazil.

Declaration of Interests: The authors certify that they have no commercial or associative interest that represents a conflict of interest in connection with the manuscript.

Corresponding Author: Manoela Domingues Martins

E-mail:manomartins@gmail.com

DOI: 10.1590/1807-3107BOR-2015.vol29.0075

Submitted: Oct 03, 2014 Accepted for publication: Feb 20, 2015 Last revision: May 13, 2015

\begin{abstract}
The aim of this study was to evaluate the demographic, clinical, and therapeutic characteristics and predictive factors of poor prognosis in patients with primary oral squamous cell carcinoma (OSCC) in Uruguay. Medical records of patients with the diagnosis of primary OSCC treated between 2000 and 2010 in Uruguayan public hospitals were selected. Data on demographic characteristics, risk factors, clinical features, treatment, and outcome were collected. Associations of independent variables with outcomes were assessed using Pearson chi-squared and Fisher's tests. Of 200 patients with OSCC, 79.4\% were men (3.8:1 male:female ratio), with a mean age of $60.75 \pm 11.26$ years. Tobacco and alcohol consumption were reported by $85.3 \%$ and $63.5 \%$ of patients, respectively. The most commonly affected location was the tongue (42.5\%), with lesions exhibiting ulcerous aspects in $87.9 \%$ of cases and pain at the time of diagnosis in $70.4 \%$ of cases. One hundred sixty-one (82.1\%) patients had advanced-stage (III/IV) OSCC. Surgery was the most common treatment option, and the overall 5-year survival rate was $58.5 \%$. Univariate analysis showed that the predictors of poor prognosis were clinical aspect, size, regional metastasis, clinical stage, and treatment. In Uruguay, OSCC is diagnosed late, which is associated with a low survival rate. Educational and preventive measures and investment to improve early diagnosis should be undertaken.
\end{abstract}

Keywords: Mouth Neoplasms; Epidemiology; Prognosis; Delayed Diagnosis.

\section{Introduction}

Oral cancer (OC) represents a health problem worldwide due to its high morbidity and mortality. ${ }^{1}$ Approximately $90 \%$ of OCs are oral squamous cell carcinoma (OSCC). ${ }^{2}$ This disease usually has a poor prognosis, with a 5 -year survival rate $<50 \%$, as most cases are diagnosed at advanced stages. ${ }^{3}$

Each year, 274,000 new cases of OC are diagnosed worldwide. ${ }^{4}$ Epidemiological studies have shown that the prevalence of OC differs significantly among continents and within the same country, and has been linked to the incidence of risk factors. ${ }^{5,6}$ Knowledge of the epidemiological profile of OC in developing regions worldwide will help to determine the extent of the problem and guide health policy decisions. Several studies had described theincidence and patterns of OC in different parts of the world, $3,7,8,9,10,11$ but studies of the Uruguayan population, especially those focusing on $\mathrm{OC}$, are scarce. ${ }^{12,13,14}$ 
Between 2002 and 2006, 1,065 cases of oropharyngeal cancer were diagnosed in Uruguay, corresponding to rates of 10.29 cases per 100,000 men and 2.64 cases per 100,000 women. ${ }^{12}$ Other studies performed in Uruguay have focused on risk factors related to pharyngeal cancer. ${ }^{13,14}$ To our knowledge, no study describing the incidence of OC in Uruguay has been published. Theaims of the present study were to evaluate the demographic and clinical features of patients diagnosed with primary OSCC at public health services in Uruguay, and to determine the predictive factors of poor prognosis in these patients. A comparative analysis with different populations was also conducted to identify discrepancies that may point to disparate etiological and predisposing factors and/or clinical behaviors of OSCC.

\section{Methodology}

This transverse observational study was approved by the Ethics Committee on Human Research of the Faculty of Dentistry, UdelaR, and the COMPESQ-Odonto (no. 21874).

\section{Study population}

A total of 368 cases of patients with clinical and histopathological diagnoses of primary OSCC (International Classification of Diseases for Oncology code 8070/3) evaluated between January 2000 and December 2010 at 37 public health services were identified using the database of the National Cancer Institute of Montevideo. Medical records of 291 patients were available and were evaluated manually, with the collection of information about sociodemographic characteristics (gender, age, skin color, occupation), risk factors (smoking habit, alcohol consumption), clinical features [lesion location, main clinical aspect (patch, plaque, papule, nodule, ulcer), presence of pain, clinical stage according to the tumor, nodes, and metastasis (TNM) classification ${ }^{15}$, treatment (surgery, radiotherapy, chemotherapy, associated treatments), evolution (life or death), and tumor relapse.

\section{Inclusion criteria}

Patients for whom medical records contained at least $70 \%$ of the information required for the study were included.

\section{Exclusion criteria}

Cases of OSCC that involved non-intraoral regions (lips, pharynges), those in which the primary site was not identified, and those for which histopathological reports were not available were excluded.

Two hundred cases were included in the study; the evolution of 77 of these cases was unknown.

\section{Statistical analysis}

The existence of associations between independent variables and outcomes (clinical stage and evolution) was assessed using the Pearson chi-squared test and Fisher's test, with a $5 \%$ significance level. SPSS software (version 15.0 for Windows; SPSS Inc., Chicago, USA) was used for all statistical analyses.

\section{Results}

Sample characteristics are summarized in Table 1. The male:female ratio was 3.8:1 and the mean age at the time of diagnosis was $60.75 \pm 11.26$ (range, 24-94) years. Regarding tobacco use, 85.3\% of patients reported being smokers and $68.8 \%$ of them smoked > 50 cigarettes/day. Alcohol consumption was reported by $63.5 \%$ of patients. Table 2 shows associations between patient sex and tobacco and alcohol consumption. OSCC was associated with tobacco and alcohol consumption only among male patients $(\mathrm{p}<0.000)$.

Painful symptomatology at the time of diagnosis was reported by $70.4 \%$ of patients, and the most common anatomic site affected by OSCC was the tongue, accounting for $42.5 \%$ of all cases (Table 1). OSCC distribution was not associated with patient $\operatorname{sex}(p=0.543)$. The majority of patients had the main clinical aspect of ulcer $(87.9 \%)$, high $\mathrm{T}(68.5 \%)$ and $\mathrm{N}$ (54.7\%) scores, and no distant metastasis (87.5\%). One hundred sixty-one $(82.1 \%)$ patients had advanced-stage (TNM III/IV) OSCC (Table 1).

Surgery was the most common treatment for OSCC. A total of 94 (49.4\%) patients underwent surgery; $23(12.1 \%)$ were treated with surgery exclusively and $71(37.4 \%)$ received adjuvant radiotherapy. Of the 123 cases for which evolution data were available, $58.5 \%$ were alive and $41.5 \%$ patients were dead. Ninety-one $(79.8 \%)$ patients were tumor free. 
Table 1. Descriptive analysis of individual variables and lesion characteristics of patients with oral squamous cell carcinoma. ( $N=200)$

\begin{tabular}{|c|c|c|c|c|c|}
\hline Variable & $\begin{array}{c}\text { Absolute } \\
\text { frequency }\left(n^{\circ}\right)\end{array}$ & $\begin{array}{c}\text { Relative } \\
\text { frequency (\%) }\end{array}$ & Variable & $\begin{array}{c}\text { Absolute } \\
\text { frequency }\left(n^{\circ}\right)\end{array}$ & $\begin{array}{c}\text { Relative } \\
\text { frequency (\%) }\end{array}$ \\
\hline Skin color & & & Anatomic site & & \\
\hline Withe & 189 & 96.9 & Tongue & 85 & 42.5 \\
\hline Black & 6 & 3.1 & Palate & 35 & 17.5 \\
\hline Missing & 5 & & Floor of the mouth & 27 & 13.5 \\
\hline Gender & & & Others & 53 & 26.5 \\
\hline Male & 158 & 79.4 & Clinicals aspects & & \\
\hline Female & 41 & 20.6 & Patch/plaque/papule/nodule & 21 & 12.1 \\
\hline Missing & 1 & & Ulcer & 152 & 87.9 \\
\hline Occupation & & & Missing & 27 & \\
\hline Non-manual workers & 66 & 34.9 & Size & & \\
\hline Domestics workers and retired & 39 & 20.6 & $\mathrm{~T} 1 / \mathrm{T} 2$ & 63 & 31.5 \\
\hline Manual workers and unemployed & 84 & 44.4 & $\mathrm{~T} 3 / \mathrm{T} 4$ & 137 & 68.5 \\
\hline Missing & 11 & 44.4 & Regional metastasis & & \\
\hline Residence & & & NO & 87 & 45.3 \\
\hline Urban & 179 & 91.8 & $\mathrm{~N} 1, \mathrm{~N} 2$ and N3 & 105 & 54.7 \\
\hline Rural & 16 & 8.2 & Missing & 8 & \\
\hline Missing & 5 & & Distant metastasis & & \\
\hline Tobacco consumption & & & MX & 20 & 10 \\
\hline Yes & 168 & 85.3 & MO & 175 & 87.5 \\
\hline No & 29 & 14.7 & Ml & 5 & 2.5 \\
\hline Missing & 3 & & Clinical stage & & \\
\hline Amount of tobacco & & & l/II & 35 & 17.9 \\
\hline$>50$ cigarettes/day & 97 & 68.8 & III/IV & 161 & 82.1 \\
\hline$\leq 50$ cigarettes/day & 44 & 31.3 & Missing & 4 & \\
\hline$\leq 50$ cigareftes/day & 44 & 31.3 & Treatment & & \\
\hline Missing & 27 & & Surgical & 23 & 12.1 \\
\hline Alcohol consumption & & & Radiotherapy & 86 & 45.3 \\
\hline Yes & 125 & 63.5 & Adjuvant (surgery followed by radiotherapy) & 71 & 37.4 \\
\hline No & 72 & 36.5 & Untreated & 10 & 5.3 \\
\hline Missing & 3 & & Missing & 10 & \\
\hline Pain & & & Evolution & & \\
\hline Yes & 100 & 70.4 & Life & 72 & 58.5 \\
\hline No & 42 & 29.6 & Dead & 51 & 41.5 \\
\hline Missing & 58 & & Missing & 77 & \\
\hline
\end{tabular}

Table 2. Association between gender and use of tobacco and alcohol.

\begin{tabular}{|c|c|c|c|c|c|c|}
\hline & \multicolumn{2}{|c|}{ Tobacco } & \multirow{2}{*}{$p$-value } & \multicolumn{2}{|c|}{ Alcohol } & \multirow{2}{*}{$p$-value } \\
\hline & Yes & No & & Yes & No & \\
\hline Male & 149 (89.2\%) & $8(27.6 \%)$ & $<0.000^{\S}$ & 119 (96\%) & 38 (52.8\%) & $<0.000^{\S}$ \\
\hline Female & 18 (10.8\%) & 21 (72.4\%) & & $5(4 \%)$ & 34 (47.2\%) & \\
\hline Total & 167 (100\%) & 29 (100\%) & & 124 (100\%) & 72 (100\%) & \\
\hline
\end{tabular}

\$Fisher's exact test.

\section{Univariate Analysis}

Analysis of clinical stage as the outcome $(n=200)$ showed that the majority of patients with advanced-stage (TNM III/IV) OSCC were smokers $(p=0.04)$, especially heavy smokers $(p=0.18)$, and presented with the clinical aspect of oral ulcer $(p=0.009$; Table 3). Treatment choice was not associated significantly with clinical stage, but all patients who received palliative or no treatment had stage III/IV OSCC. In the analysis of evolution as the outcome $(\mathrm{n}=123)$, surgical treatment (associated or not with radio/chemotherapy) was shown to be the most effective treatment; $66.6 \%$ of patients who received such treatment lived (Table 4). 
- A 10-year analysis of the oral squamous cell carcinoma profile in patients from public health centers in Uruguay

Table 3. Associations between clinical stage and variables. $(N=200)$

\begin{tabular}{|c|c|c|c|}
\hline \multirow{2}{*}{ Variable/Category } & \multicolumn{2}{|c|}{ Clinical Stage } & \multirow[b]{2}{*}{$p$-value* } \\
\hline & $\mid / I I$ & III/IV & \\
\hline \multicolumn{4}{|l|}{ Gender } \\
\hline Male & 25 (71.4\%) & $129(80.6 \%)$ & $0.227 \S$ \\
\hline Female & $10(28.6 \%)$ & 31 (19.4\%) & \\
\hline Missing & 0 & 1 & \\
\hline \multicolumn{4}{|l|}{ Occupation } \\
\hline Non-manual workers & $16(47.1 \%)$ & 49 (32.5\%) & $0.231^{\#}$ \\
\hline Domestics workers/retired & $7(20.6 \%)$ & $32(21.2 \%)$ & \\
\hline Manual workers/unployed & $11(32.4 \%)$ & $70(46.4 \%)$ & \\
\hline Missing & 1 & 10 & \\
\hline \multicolumn{4}{|l|}{ Residence } \\
\hline Urban & 31 (93.9\%) & $144(91.1 \%)$ & $0.597 \S$ \\
\hline Rural & $2(6.1 \%)$ & 14 (8.9\%) & \\
\hline Missing & 2 & 3 & \\
\hline \multicolumn{4}{|l|}{ Tobacco consumption } \\
\hline Yes & 25 (73.5\%) & 139 (87.4\%) & $0.040^{\S}$ \\
\hline No & 9 (26.5\%) & $20(12.6 \%)$ & \\
\hline Missing & 1 & 2 & \\
\hline \multicolumn{4}{|l|}{ Amount of tabacco } \\
\hline$>50$ cigarettes/day & $9(45.0 \%)$ & $83(71.8 \%)$ & $0.018^{\S}$ \\
\hline$\leq 50$ cigarettes/day & $11(55.0 \%)$ & $33(28.2 \%)$ & \\
\hline Missing & 5 & 23 & \\
\hline \multicolumn{4}{|l|}{ Alcohol consumption } \\
\hline Yes & 19 (55.9\%) & $103(64.8 \%)$ & $0.329 \S$ \\
\hline No & $15(44.1 \%)$ & $56(35.2 \%)$ & \\
\hline \multicolumn{4}{|l|}{ Pain } \\
\hline Yes & $11(55.0 \%)$ & $86(72.9 \%)$ & $0.106^{\S}$ \\
\hline No & $9(45.0 \%)$ & $32(27.1 \%)$ & \\
\hline Missing & 15 & 43 & \\
\hline \multicolumn{4}{|l|}{ Anatomic site } \\
\hline Tongue & 15 (42.9\%) & $67(41.6 \%)$ & $0.604^{\#}$ \\
\hline Palate & $5(14.3 \%)$ & $30(18.6 \%)$ & \\
\hline Floor of the mouth & $3(8.6 \%)$ & $23(14.3 \%)$ & \\
\hline Other & $12(34.3 \%)$ & $41(25.5 \%)$ & \\
\hline \multicolumn{4}{|l|}{ Clinicals aspects } \\
\hline Patch/plaque/papule/nodule & $7(26.9 \%$ & $13(9.0 \%)$ & $0.009^{\S}$ \\
\hline Ulcer & 19 (73.1\%) & $131(91.0 \%)$ & \\
\hline Missing & 8 & 17 & \\
\hline \multicolumn{4}{|l|}{ Size } \\
\hline $\mathrm{T} 1 / \mathrm{T} 2$ & 35 (100\%) & 24 (14.9\%) & $<0.000^{\S}$ \\
\hline T3/T4 & 0 & $137(85,1 \%)$ & \\
\hline \multicolumn{4}{|l|}{ Regional metastasis } \\
\hline NO & 35 (100\%) & $52(33.1 \%)$ & $<0.000^{\S}$ \\
\hline $\mathrm{N} 1, \mathrm{~N} 2$ or N3 & 0 & $105(66.9 \%)$ & \\
\hline Missing & 0 & 4 & \\
\hline \multicolumn{4}{|l|}{ Treatment } \\
\hline Surgical & 7 (20.6\%) & $16(10.5 \%)$ & $0.170^{\#}$ \\
\hline Radiotherapy & $13(38.2 \%)$ & $70(46.1 \%)$ & \\
\hline Adjuvant (surgery followed by radiotherapy) & $14(41.2 \%)$ & $56(36.8 \%)$ & \\
\hline Untreated & 0 & $10(6.6 \%)$ & \\
\hline Missing & 1 & 9 & \\
\hline
\end{tabular}

§Fisher's exact test.

\#Pearson Chi-square test. 
Table 4. Association between evolution and variables. ( $N=123$ )

\begin{tabular}{|c|c|c|c|}
\hline \multirow{2}{*}{ Variable/Category } & \multicolumn{2}{|c|}{ Evolution } & \multirow[b]{2}{*}{$p$-value* } \\
\hline & Life & Dead & \\
\hline \multicolumn{4}{|l|}{ Gender } \\
\hline Male & $53(73.6 \%)$ & $43(86.0 \%)$ & $0.100 \S$ \\
\hline Female & 19 (26.4\%) & 7 (14.0\%) & \\
\hline Missing & 0 & 1 & \\
\hline \multicolumn{4}{|l|}{ Occupation } \\
\hline Non manual workers & $22(31.9 \%)$ & 20 (42.6\%) & $0.421^{\#}$ \\
\hline Domestics workers/retired & $19(27.5 \%)$ & $9(19.1 \%)$ & \\
\hline Manual workers/unployed & $28(40.6 \%)$ & $18(38.3 \%)$ & \\
\hline Missing & 3 & 4 & \\
\hline \multicolumn{4}{|l|}{ Residence } \\
\hline Urban & $64(90.1 \%)$ & 45 (93.8\%) & $0.486^{\S}$ \\
\hline Rural & $7(9.9 \%)$ & $3(6.3 \%)$ & \\
\hline Missing & 1 & 3 & \\
\hline \multicolumn{4}{|l|}{ Tobacco consumption } \\
\hline Yes & 56 (78.9\%) & 45 (90.0\%) & $0.105^{\S}$ \\
\hline No & $15(21.1 \%)$ & 5 (10.0\%) & \\
\hline Missing & 1 & 1 & \\
\hline \multicolumn{4}{|l|}{ Amount of tabacco } \\
\hline$>50$ cigarettes/day & $30(65.2 \%)$ & $28(65.1 \%)$ & $0.992^{\S}$ \\
\hline $\begin{array}{l}\leq 50 \text { cigarettes/day } \\
\text { Missing }\end{array}$ & $\begin{array}{c}16(34.8 \%) \\
10\end{array}$ & $\begin{array}{c}15(34.9 \%) \\
2\end{array}$ & \\
\hline \multicolumn{4}{|l|}{ Alcohol consumption } \\
\hline Yes & $41(57.7 \%)$ & 35 (70.0\%) & $0.170^{\S}$ \\
\hline No & $30(42.3 \%)$ & 15 (30.0\%) & \\
\hline \multicolumn{4}{|l|}{ Pain } \\
\hline Yes & $28(60.9 \%)$ & 36 (78.3\%) & $0.070^{\S}$ \\
\hline No & $18(39.1 \%)$ & $10(21.7 \%)$ & \\
\hline Missing & 26 & 5 & \\
\hline
\end{tabular}

\$Fisher's exact test.

\#Pearson Chi-square test.

\section{Discussion}

The study of OSCC is extremely important, due to its high morbidity and mortality. ${ }^{2}$ One of the most difficult aspects of this disease is its control, and little improvement in the survival rate has been achieved over the last 50 years. ${ }^{3}$ Epidemiological studies are important to gain an understanding of changes in the cancer profile in a specific geographic location. ${ }^{7,8,910}$ However, studies involving sizeable cohorts of Uruguayan patients with OSCC are lacking. The majority of previous studies investigated carcinomas of the oral cavity and pharynx without discriminating data according to region. ${ }^{11,12,13,14}$ The present study was the first to assess the demographic aspects, clinical presentation, treatment modalities, and prognostic factors of OSCC in a representative sample of patients who visited public health services in Uruguay.

\begin{tabular}{|c|c|c|c|}
\hline \multirow{2}{*}{ Variable/Category } & \multicolumn{2}{|c|}{ Evolution } & \multirow[b]{2}{*}{$\mathrm{p}$-value* } \\
\hline & Life & Dead & \\
\hline \multicolumn{4}{|l|}{ Anatomic site } \\
\hline Tongue & 25 (34.7\%) & 28 (54.9\%) & $0.055^{\sharp}$ \\
\hline Palate & $13(18.1 \%)$ & $8(15.7 \%)$ & \\
\hline Floor of the mouth & $8(11.1 \%)$ & $7(13.7 \%)$ & \\
\hline Other & $26(36.1 \%)$ & $8(15.7 \%)$ & \\
\hline \multicolumn{4}{|l|}{ Clinicals aspects } \\
\hline Patch/plaque/papule/nodule & $13(21.7 \%)$ & $3(6.1 \%)$ & $0.020^{\S}$ \\
\hline Ulcer & $47(78.3 \%)$ & $46(93.9 \%)$ & \\
\hline Missing & 12 & 2 & \\
\hline \multicolumn{4}{|l|}{ Size } \\
\hline $\mathrm{T} 1 / \mathrm{T} 2$ & $32(44.4 \%)$ & $5(9.8 \%)$ & $<0.000^{\$}$ \\
\hline $\mathrm{T} 3 / \mathrm{T} 4$ & $40(55.6 \%)$ & 46 (90.2\%) & \\
\hline \multicolumn{4}{|l|}{ Regional metástasis } \\
\hline NO & $44(61.1 \%)$ & $17(34.0 \%)$ & $0.016^{\S}$ \\
\hline $\mathrm{N} 1, \mathrm{~N} 2$ or N3 & $28(38.9 \%)$ & $33(66.0 \%)$ & \\
\hline Missing & 0 & 1 & \\
\hline \multicolumn{4}{|l|}{ Clinical stage } \\
\hline I/II & 20 (27.8\%) & $3(5.9 \%)$ & $0.002^{\S}$ \\
\hline III/IV & $52(72.2 \%)$ & $48(94.1 \%)$ & \\
\hline \multicolumn{4}{|l|}{ Treatment } \\
\hline Surgical & 15 (20.8\%) & $3(5.9 \%)$ & $<0.000^{\sharp}$ \\
\hline Radiotherapy & $23(31.9 \%)$ & $28(54.9 \%)$ & \\
\hline Adjuvant (surgery followed by radiotherapy) & $33(45.8 \%)$ & $13(25.5 \%)$ & \\
\hline Untreatment & $1(1.4 \%)$ & 7 (13.7\%) & \\
\hline \multicolumn{4}{|l|}{ Recidive } \\
\hline Yes & $15(21.1 \%)$ & $8(19.0 \%)$ & $0.791^{\S}$ \\
\hline No & $56(78.9 \%)$ & $34(81.0 \%)$ & \\
\hline
\end{tabular}

Most general characteristics observed in our study were consistent with previous reports that the majority of OSCC occurs in males, with a higher incidence in individuals in the sixth and seventh decades of life. ${ }^{3,8}$ Previous studies have revealed that OSCC occurs at an earlier age in men than in women, ${ }^{16}$ whereas mean ages at the time of diagnosis were similar in men (60.57 \pm 9.94 years) and women (61.07 \pm 15.43 years) in our study. The male:female ratio in our study is higher than those reported from other countries. ${ }^{9}$ Smoking and alcoholism have been implicated widely as risk factors for OSCC, ${ }^{3}$ and synergistic use is known to have a multiplicative effect. In our study, $89.2 \%$ of smokers and $96 \%$ of patients who consumed alcohol were male, similar to previously reported resultss. ${ }^{3} \mathrm{We}$ can thus infer that male patients are more involved with tobacco and alcohol use than women in Uruguay. De Stefani et al. ${ }^{13}$ observed that smoking and drinking 
were associated more frequently with OSCC than with pharyngeal cancer in Uruguay. In contrast, previous studies revealed that these common risk factors were not associated with tumor development in young and/or female patients. ${ }^{9}$ The cause of OSCC development in young and/or female patients without typical risk factors remains unclear; family cancer history (hereditary aspect), genetic predisposition to environmental carcinogenesis, drug abuse, viral infection, immunodeficiency, and diet have been suggested as possible risk factors, but no strong evidence supports these hypotheses. ${ }^{17}$

The limits of the oral cavity are defined variably; some authors include the lips, ${ }^{2}$ whereas others do not. ${ }^{18}$ In the present study, OSCC in the lips was excluded because this site presents different carcinogenesis (sun exposure) and better evolution than intraoral carcinomas. Our data revealed that the tongue was the most frequently affected intraoral site, as described in previous studies. ${ }^{3,13}$ The diagnosis of tongue cancer is usually delayed, allowing for local extension and metastatic spread, and thereby resulting in a poorer outcome. ${ }^{9}$ The predilection for this region may be associated with the pooling of carcinogens in saliva, creating risk zones. ${ }^{16}$ However, geographic and cultural differences may be linked to the intraoral distribution of OSCC. In India and nearby areas, the most frequent site of $\mathrm{OC}$ is the buccal mucosa, as a repercussion of the habit of smokeless tobacco use. ${ }^{19}$

The TNM classification is very useful for the definition of treatment modality, and it has been associated with prognosis. ${ }^{8}$ In keeping with the literature, $82.1 \%$ of our patients had advanced (stage III/IV) OSCC, which indicates late diagnosis. Several studies have addressed this issue. ${ }^{3,8,16}$ One explanation for late diagnosis is the absence of pain in the early stages of OSCC. In agreement, we observed that pain was more frequent in advanced (72.9\%) than in early (55\%) stages. Groome et al..$^{20}$ found that anterior tongue location, poorly differentiated cancer, presence of co-morbidities, socially marginalized patient status, current smoking, and smoking with heavy drinking were associated with late-stage OC diagnosis. Other factors related to late OSCC diagnosis are lack of regular dental care, male sex, and single status. ${ }^{20,21}$ These factors are very useful for the identification of at-risk groups who would benefit most from targeted education and screening.

Another significant finding of our study was the association of late-stage OSCC with excessive smoking habit and the presence of ulcer. Previous studies have also associated the amount of tobacco consumed with more advanced clinical stages. ${ }^{20}$ The ulcerative aspect is the main clinical manifestation of all stages of OSCC. However, especially in advanced tumors, ulceration is an important finding and represents the focus of tissue necrosis due to the tumor's rapid growth.

The most important findings of our study were related to the impacts of several variables on patient survival. Univariate analysis showed that the predictors of poor prognosis were clinical aspect, size, regional metastasis, clinical stage, and treatment modality. The majority of patients who died presented an ulcerous aspect, T3/T4 tumor size, regional metastasis, and TNM stage III/IV OSCC. These results emphasize the utility of the classical TNM staging system for determining OSCC prognosis. All of these factors have been associated previously with poor prognosis. ${ }^{8,22}$ The predictive value of ulcerative form for the survival of patients with OSCC is controversial, although ulcerative lesions are accepted to involve poorer prognosis. ${ }^{23}$ According to the literature, the most important clinical predictor of survival remains TNM stage at the time of diagnosis. Cervical lymph-node metastasis is widely accepted to be the strongest independent prognostic factor in patients with OSCC.8,24 The cure rate declines by approximately $50 \%$ when lymph node metastasis occurs. ${ }^{24}$

Important advances have been made in OSCC research in all related fields; however, surgery combined with neoadjuvant therapies remains the best therapeutic choice. New concepts, such as induction chemotherapy before radiotherapy or chemoradiotherapy, and multiagent treatment, are emerging. In a randomized controlled trial, Mishra et al. ${ }^{25}$ demonstrated that the addition of adjuvant radiotherapy to surgery significantly improved disease-free survival in patients with stage III/IV OSCC. In confirmation of this finding, our results showed that more patients who received surgery alone 
or with neoadjuvant radio/chemotherapy lived than did those who received only radio/chemotherapy. Other studies have yielded similar results. ${ }^{9}$ The importance of early diagnosis is also related to treatment options, as patients with advanced-stage inoperable tumors can receive only radio/chemotherapy as palliative treatment, worsening their prognoses.

Studies of OSCC in the Uruguayan population, especially those focusing on prognosis, are scarce. Although the methodology and results of our study do not differ considerably from those of studies conducted in other countries and the lack of information in the patients' medical records is an important limitation, we believe that the retrospective analysis of data obtained from patients in specific geographic areas is of great importance, especially when the demographic profile of the population is unknown. Considering the importance of OC and the late diagnosis observed

\section{References}

1. Lambert R, Sauvaget C, de Camargo M, Sankaranarayanan R. Epidemiology of cancer from the oral cavity and oropharynx. Eur J Gastroenterol Hepatol. 2011 Aug;23(8):633-41.

2. Zini A, Czerninski R, Sgan-Cohen HD. Oral cancer over four decades: epidemiology, trends, histology, and survival by anatomical sites. J Oral Pathol Med. 2010 Apr;39(4):299-305.

3. Seoane-Romero JM, Vázquez-Mahía I, Seoane J, Varela-Centelles P, Tomás I, López-Cedrún JL. Factors related to late stage diagnosis of oral squamous cell carcinoma. Med Oral Patol Oral Cir Bucal. 2012 Jan 1;17(1):e35-40.

4. Ferlay J, Shin HR, Bray F, Forman D, Mathers C, Parkin DM. GLOBOCAN 2008. Cancer incidence and mortality worldwide; Lyon, France: IARC Cancer Base. 2010 [cited 2013 Aug 20] Available from: http://globocan.iarc.fr.

5. Instituto Nacional do Câncer [homepage]. Rio de Janeiro: Instituto Nacional do Câncer; 2012 [cited 2013 Aug 20]. Available from: http://www.inca.gov.br.

6. Jemal A, Siegel R, Ward E, Murray T, Xu J, Thun M. Cancer Statistics, 2007. CA Cancer J Clin. 2007 Jan-Feb;57(1):43-66.

7. Ganly I, Patel S, Shah J. Early stage squamous cell cancer of the oral tongue--clinicopathologic features affecting outcome. Cancer. 2012 Jan;118(1):101-11.

8. Kreppel M, Drebber U, Rothamel D, Eich HT, Kübler A, Scheer M, et al. Prognostic impact of different TNM-based stage groupings for oral squamous cell carcinoma. Head Neck. 2011 Oct;33(10):1467-75.

9. Ling W, Mijiti A, Moming A. Survival pattern and prognostic factors of patients with squamous cell carcinoma of the in this study, the Uruguayan government and health professionals should consider the development of plans for prevention and early detection of these lesions. OSCC could be detected early with a simple oral examination; however, compared with other types of cancer that are not detectable by visual examination and involve more elaborate screening (e.g., prostate, breast, chest, colon), the rate of early OSCC diagnosis has not improved over time. Education about OSCC risk factors and the clinical aspects of $\mathrm{OC}$ is important to promote self-examination.

\section{Conclusion}

In Uruguay, OSCC is frequently diagnosed late, which is associated with a low 5-year survival rate. Educational and preventive measures and investment in strategies to improve early diagnosis should be a goal in that country.

tongue: a retrospective analysis of 210 cases. J Oral Maxilofac Surg. 2013 Apr;71(4):775-85.

10. Monteiro L, Amaral JB, Vizcaíno JR, Lopes CA, Torres FO. A clinical-pathological and survival study of oral squamous cell carcinomas from a population of the north of Portugal. Med Oral Patol Oral Cir Bucal. 2014 Mar;19(2):e120-6

11. De Stefani E, Boffetta P, Oreggia F, Fierro L, Mendilaharsu M. Hard liquor drinking is associated with higher risk of cancer of the oral cavity and pharynx than wine drinking, a case-control study in Uruguay. Oral Oncol. 1998 Mar;34(2):99-104.

12. Barrios E, Vassallo J, Alonso R, Garau M, Musetti C. III Atlas de incidencia del cáncer en el Uruguay 2002-2006. Montevideo. Comisión Honoraria de Lucha Contra el Cáncer. 2010; 58 p.

13. De Stefani E, Boffetta P, Deneo-Pellegrini H, Ronco A, Acosta G, Ferro G, et al. The effect of smoking and drinking in oral and pharyngeal cancer: a case control study in Uruguay. Cancer Lett. 2007 Feb;246(1-2):282-89.

14. Deneo-Pellegrini H, De Stefani E, Boffetta P, Ronco AL, Acosta G, Correa P, et al. Maté consumption and risk of oral cancer: Case-control study in Uruguay. Head Neck. 2013 Aug;35(8):1091-5.

15. Patel S, Lydiatt W. Staging of head and neck cancers: is it time to change the balance between the ideal and the practical? J Surg Oncol. 2008 Jun;97(8):653-57.

16. Brandizzi D, Gandolfo M, Velazco M, Cabrini R, Lanfranchi $\mathrm{H}$. Clinical features and evolution of oral cancer: A study of 274 cases in Buenos Aires, Argentina. Med Oral Patol Oral Cir Bucal. 2008 Sep;13(9):e544-8. 
17. Galbiatti AL, Padovani-Junior JA, Maníglia JV, Rodrigues CD, Pavarino EC, Goloni-Bertollo EM. Head and neck cancer: causes, prevention and treatment. Braz J Otorhinolaryngol. 2013 Mar-Apr;79(2):239-47.

18. Carvalho A, Lago N, Ferreira A, Mendonça E, Gonçalves $\mathrm{R}$, Silva T. Distinctive clinical and microscopic features of squamous cell carcinoma of oral cavity and lip. Oral Surg Oral Med Oral Pathol Oral Radiol Oral Endod. 2010 Mar;109(3):e74-9.

19. Ghoshal S, Mallick I, Panda N, Sharma S. Carcinoma of the buccal mucosa: analysis of clinical presentation, outcome and prognostic factors. Oral Oncol. 2006 May;42(5):533-39.

20. Groome PA, Rohland SL, Hall SF, Irish J, Mackillop WJ, O'Sullivan B. A population-based study of factors associated with early versus late stage oral cavity cancer diagnoses. Oral Oncol. 2011 Jul;47(7):642-7.

21. Kowalski LP, Franco EL, Torloni H, Fava AS, Andrade Sobrinho J, Ramos G, et al. Lateness of diagnosis of oral and oropharyngeal carcinoma: factors related to the tumour, the patient and health professionals. Eur J Cancer B Oral Oncol. 1994 May;30B(3):167-73.

22. Sato J, Yamazaki Y, Satoh A, Onodera-Kyan M, Abe T, Satoh T. Pain may predict poor prognosis in patients with oral squamous cell carcinoma. Oral Surg Oral Med Oral Pathol Oral Radiol Endod. 2011 May;111(5):587-92.

23. Jaulerry C, Bataini JP, Brunin F, Rodriguez J, Brugère J. Prognostic factors and results of external irradiation of cancers of the base of the tongue. Ann Otolaryngol Chir Cervicofac. 1985;102(7):519-24.

24. Süslü N, Hoşal AS, Aslan T, Sözeri B, Dolgun A. Carcinoma of the oral tongue: a case series analysis of prognostic factors and surgical outcomes. J Oral Maxillofac Surg. 2013 Jul;71(7):1283-90.

25. Mishra RC, Singh DN, Mishra TK. Post-operative radiotherapy in carcinoma of buccal mucosa, a prospective randomized trial. Eur J Surg Oncol. 1996 Oct;22(5):502-4. 